Journal of Clinical Investigation

Vol. 42, No. 10, 1963

\title{
STUDIES OF THE ADRENAL ANTIGENS AND ANTIBODIES IN ADDISON'S DISEASE*
}

\author{
By R. M. BLIZZARD ANd M. KYLE \\ (From the Department of Pediatrics, The Johns Hopkins School of Medicine and Hospital, \\ Baltimore, $M d$.)
}

(Submitted for publication March 26, 1963; accepted July 8, 1963)

Certain criteria $(1,2)$ must be met in order to prove that autosensitization or autoimmune disease is related to observed pathological findings. These are: 1) the direct demonstration of specific antibodies of the circulating type, or the demonstration by indirect means of the cell-bound type of antibody ; 2) the characterization or isolation of the specific antigen against which these antibodies are directed; 3) the production of antibodies against the same type of antigen in experimental animals; and 4) the appearance of pathological changes that are basically similar to those in the human disease in the corresponding tissues of an actively sensitized animal.

All the criteria have been met in Hashimoto's thyroiditis and spontaneous hypothyroidism, and these are now regarded as autoimmune diseases. Since idiopathic Addison's disease results from atrophy of the adrenal gland similar to the thyroidal atrophy occurring in spontaneous myxedema, it is reasonable to postulate that an autoimmune process may be related to the development of idiopathic Addison's disease.

In the present study, a high incidence of circulating adrenal antibodies was demonstrated in the sera of 71 Addisonian patients. The organ and species specificities of the adrenal antigen(s) have also been determined, and some physical characteristics of the circulating antibodies have been elucidated. The findings further satisfy the criteria above and suggest that some cases of idiopathic Addison's disease may be the result of an autoimmune phenomenon.

\section{METHODS}

The diagnosis of Addison's disease was clearly established in all instances. All patients required mineral corticoid therapy, with one exception (Table I, no. 27).

* Work supported by U. S. Public Health Service grant A-4499, National Institutes of Health, Bethesda, Md.
The duration of Addison's disease for 26 of these patients has been published previously (3). Since no correlation between onset and the presence of circulating antibodies was found, no further tabulation has been made.

The methods of collecting and storing sera and tissue have previously been described (3). The indirect Coons test was performed with unfixed thyroid $(4,5)$ and adrenal tissue (3). Salivary, liver, kidney, and pheochromocytoma tissues were also used for testing of serum by the indirect Coons technique.

Complement-fixing (CF) antibodies to adrenal tissue were measured by the procedure of Blizzard and associates (6) for determining thyroidal CF antibodies, but with the following modifications: 1) extracts of adrenal tissue were used without addition of saturated ammonium sulfate and without dialysis, and 2) in the final reading, the extent of hemolysis was determined by noting the size of the red erythrocyte pellet after gentle centrifugation of the tubes for 1 minute. Positive results, or failures of hemolysis to occur, were recorded 1 to $4+$. All $1+$ reactions were considered equivocal and were therefore recorded as negative in Tables I and II. Identical techniques were used for measuring $\mathrm{CF}$ antibodies to kidney tissue.

Tissue extracts for absorption or inhibition studies were prepared like those for the CF test. A $0.1-\mathrm{ml}$ vol of the extract was added to $0.1 \mathrm{ml}$ of appropriately diluted serum. The monilial extract was prepared from a culture from a patient with generalized moniliasis. The fungus colonies were scraped from the Sabaroud's medium and washed twice with 5 to 10 times as much normal saline as packed monilial cells. The cells were resuspended in normal saline to form a $50 \%$ suspension (wt: vol) divided into two portions $A$ and $B$. Portion $\mathrm{B}$ of this material, while kept close to $0^{\circ} \mathrm{C}$, was exposed to ultrasonic vibration for 15 minutes at about 20,000 cycles per minute and was then centrifuged in an International centrifuge for 5 minutes at $3,200 \mathrm{rpm}$ to separate the cellular debris. A $0.1-\mathrm{ml}$ vol of $A$ and $0.1 \mathrm{ml}$ of supernatant fluid from $B$ were then added to separate tubes containing $0.1 \mathrm{ml}$ of undiluted and doubling dilutions of positive serum. This mixture was incubated for at least 30 minutes at $37^{\circ} \mathrm{C}$ before use in the Coons test. Comparably diluted positive serums were used simultaneously as controls.

The microsomes and mitochondria used in the inhibition tests were prepared from trimmed, weighed, and minced tissue. A $10 \%$ homogenate was made in $0.25 \mathrm{M}$ 
TABLE I

Antibodies in sera of Addisonian patients*

\begin{tabular}{|c|c|c|c|c|c|c|}
\hline \multirow[b]{2}{*}{ Patient no. } & \multirow[b]{2}{*}{ Additional diagnosis } & \multicolumn{3}{|c|}{ Coons test (unfixed tissue) } & \multicolumn{2}{|c|}{$\begin{array}{l}\text { Complement- } \\
\text { fixation test }\end{array}$} \\
\hline & & $\begin{array}{l}\text { Sali- } \\
\text { vary }\end{array}$ & $\begin{array}{c}\text { Thy- } \\
\text { roidali }\end{array}$ & Adrenal & $\begin{array}{c}\text { Adre- } \\
\text { nal }\end{array}$ & Kid- \\
\hline 1 & & - & - & $+[\mathrm{NT}] \dagger$ & QI & QI \\
\hline 2 & & - & - & $+[1] \dagger$ & + & $\ddagger$ \\
\hline 3 & & - & - & $+[2]$ & + & - \\
\hline 4 & & - & - & $+[32]$ & + & - \\
\hline 5 & & & - & $+[\mathrm{NT}]$ & - & QI \\
\hline 6 & & + & - & $+[64]$ & $\div$ & - \\
\hline 7 & & - & - & $+[8]$ & - & - \\
\hline 8 & & - & - & $+[2]$ & - & - \\
\hline 9 & & - & - & $+[8]$ & + & - \\
\hline 10 & & + & + & $+[1]$ & + & - \\
\hline 11 & & - & + & $+[1]$ & - & - \\
\hline 12 & & - & + & $+[4]$ & + & - \\
\hline 13 & & + & + & $+[4]$ & + & QI \\
\hline 14 & & - & + & $+[8]$ & + & - \\
\hline 15 & & + & + & $+[16]$ & + & - \\
\hline 16 & & - & + & $+[2]$ & - & - \\
\hline $17 \mathrm{a}$ & & + & + & $+[8]$ & + & - \\
\hline $18^{\mathrm{a}}$ & & - & + & $+[1]$ & - & - \\
\hline 19 & TT & - & + & $+[32]$ & + & QI \\
\hline 20 & TT, DM & - & - & $+[1]$ & - & $\mathrm{QI}$ \\
\hline 21 & SM & - & + & $+[\mathrm{NT}]$ & $\div$ & - \\
\hline 22 & $\mathrm{SM}, \mathrm{DM}$ & - & - & $+[1]$ & - & - \\
\hline 23 & Goiter & - & + & $+[4]$ & + & + \\
\hline 24 & SM, DM, hypogonadism & - & + & $+[2]$ & + & - \\
\hline 25 & IH & - & - & $+[8]$ & + & - \\
\hline $26^{b}$ & IH & + & - & $+[4]$ & + & - \\
\hline $27^{\mathrm{b}}$ & IH & - & + & $+[1]$ & + & + \\
\hline 28 & IH & - & - & $+[2]$ & + & + \\
\hline 29 & $\mathrm{IH}$, monil. & + & - & $+[16]$ & + & - \\
\hline 30 & IH, monil. & - & + & $+[16]$ & QI & + \\
\hline $31^{\mathrm{e}}$ & IH., monil., PA & - & - & $+[2]$ & + & + \\
\hline $32^{\mathrm{c}}$ & & & - & $+[4]$ & + & + \\
\hline $33^{\mathrm{d}}$ & $\mathrm{IH}$, monil. & - & - & $+[8]$ & - & + \\
\hline $34^{\mathrm{d}}$ & Monil. & + & - & $+[16]$ & - & - \\
\hline $35^{d}$ & $\mathrm{IH}$ & - & - & - & - & QI \\
\hline $36^{e}$ & $\mathrm{IH}$, monil: & - & - & $+[16]$ & + & $\tilde{t}$ \\
\hline $37 \mathrm{e}$ & IH, monil. & & - & - & - & + \\
\hline $38^{\mathrm{f}}$ & IH, monil. & - & + & $+[2]$ & - & \pm \\
\hline 39 & Calcified adrenals & - & - & - & + & - \\
\hline 40 & TBC & - & - & - & + & - \\
\hline $41-43 \mathrm{~g}$ & & & - & - & - & \\
\hline $44-46^{h}$ & & - & - & - & - & \\
\hline $47-49$ & $1 \mathrm{TT}$ & - & + & - & - & \\
\hline $50-53$ & $1 \mathrm{SM}, 1$ Hash., $1 \mathrm{DM}$ & & + & - & - & \\
\hline $54-67$ & $\begin{array}{l}1 \mathrm{SM}, 1 \text { Hypopituitarism, } 1 \text { histoplasmosis } \\
1 \text { TBC, } 1 \text { Schilder's disease }\end{array}$ & & - & - & - & \\
\hline 68-70 & & - & - & - & - & \\
\hline 71 & DM & - & - & & & \\
\hline
\end{tabular}

* Symbols: Superscript letters indicate groupings of siblings. TT, thyrotoxicosis; DM, diabetes mellitus; SM, spontaneous myxedema; IH, idiopathic hypoparathyroid; monil., moniliasis; PA, pernicious anemia; TBC, tuberculosis; Hash., Hashimoto's thyroiditis. +, Positive to test; -, negative to test. Titers are given in brackets; NT, not titered. QI, quantity insufficient.

$\dagger$ Reciprocal of titer positive to test.

$\ddagger$ Anticomplementary. 
sucrose with a Potter-Elvejhem homogenizer. This suspension was centrifuged in a refrigerated model PR2International centrifuge at $2,500 \mathrm{rpm}$ for 10 minutes to separate the nuclear debris. The supernatant fluid was put in an appropriate centrifuge tube, which was filled to capacity with $0.25 \mathrm{M}$ sucrose and spun at $10,500 \mathrm{rpm}$ for 10 minutes in a Spinco preparative model $L$ ultracentrifuge to obtain the mitochondrial fraction. The mitochondria were resuspended in $0.25 \mathrm{M}$ sucrose at least once and recentrifuged at the same speed for 10 minutes. In experiment 1, Table VII, the adrenal mitochondria were washed, resuspended, and recentrifuged 3 times in an attempt to eliminate microsomal contamination. To separate the microsomes, the supernatant fluid obtained after the first mitochondrial separation was centrifuged at $35,000 \mathrm{rpm}$ for 1 hour. After removal of the resulting supernatant fluid, the microsomal layer was gently overlaid with sucrose and recentrifuged for 15 minutes at $35,000 \mathrm{rpm}$. The microsomal and mitochondrial fractions were resuspended in saline after washing. Appropriate dilutions of the cell fractions then were added to the test serum, and the mixture was incubated overnight at $4^{\circ} \mathrm{C}$. Nitrogen determinations were done by the micro-Kjeldahl technique (7), and the results multiplied by a factor, 6.25 , to determine the average protein concentration.

Immunoelectrophoresis of sera was performed with a NIL-agafor microimmunoelectrophoresis apparatus ${ }^{1}$ in $1.5 \%$ Noble agar gel in a barbital buffer at $\mathrm{pH} 8.2$ and of ionic strength 0.05 . After electrophoresis of the sera, dilutions of adrenal extracts of $1: 1,1: 2$, and $1: 4$ (wt: vol) were placed in the troughs and permitted to diffuse toward the serum for 24 to 48 hours. Precipitating antibodies to adrenal antigen were investigated by the agar slant technique (6) with adrenal extract as antigen.

\section{RESULTS}

Incidence of adrenal and other antibodies in sera of Addisonian patients. Sera of 11 of 21 children and 25 of 50 adults, or 36 of 71 patients, with Addison's disease contained circulating adrenal antibodies, as measured by the indirect Coons technique (Table I). Serum titers varied between $1: 1$ (undiluted) and 1:64. When these 36 sera were tested by the CF technique, 24 were positive, 10 were negative, and there was insufficient serum for this test from two patients. In general, sera with high antibody titers by the Coons test usually had demonstrable $\mathrm{CF}$ antibodies, and low-titered serums usually had no CF antibodies. Sera 33 and 34, from siblings, were exceptional; they had titers of $1: 8$ and $1: 16$ in the Coons test but did not have demonstrable

\footnotetext{
1 National Instruments Laboratories, Inc., Washington, D. C.
}

CF antibodies. Only two sera, no. 39 and 40, had CF antibodies when no antibodies were found by the Coons technique. Patients 39 and 40 were the only two in this series believed to have Addison's disease of tuberculous rather than idiopathic origin.

Twenty-two of the Addisonian patients had circulating antithyroid antibodies, as measured by the indirect Coons technique with unfixed thyroid slices. There was, however, no correlation between the presence of circulating thyroid and adrenal antibodies. Eight of the 36 patients with circulating adrenal antibodies (by the Coons test) had circulating antibodies to the intercalated ducts of submaxillary and parotid salivary tissue. The titers of adrenal antibodies and the presence of a positive test to salivary tissue could not be correlated. None of these patients had Sjögren's syndrome or any other known disease involving salivary tissue.

Of the 24 sera with adrenal antibodies demonstrated by both the Coons and CF methods, 6 had demonstrable $\mathrm{CF}$ antibodies against kidney tissue, 15 had no antibodies, and 3 were not tested. The presence or absence of CF antibodies to renal tissue could not be correlated with the titer of serum giving a positive Coons test for adrenal antibodies. The failure of correlation of adrenal CF antibody titers with renal CF antibodies, and the occasional positive test for $\mathrm{CF}$ antibodies to kidney tissue when no such antibodies to adrenal tissue were demonstrable, suggest that persons whose sera fixed complement when placed with kidney tissue had erythrocyte antibodies. Theoretically, the renal extracts could have contained substance $A$ or $B$, since the patients from whom kidneys were removed were not always type $O$. This possibility is unlikely, however, since the results represent repeated observations with different extracts of renal tissue.

Four of 124 persons without Addison's disease had serum adrenal antibodies demonstrable by the fluorescein technique, and none had CF antibodies (Table II). All four of these subjects had idiopathic hypoparathyroidism. Sera of 23 patients with idiopathic hypoparathyroidism, 29 patients (no. 96 to 124) with adrenal disease other than Addison's disease, and 68 subjects with neither adrenal nor parathyroid disease gave negative results to testing. 
TABLE II

Antibodies in sera of non-Addisonian patients *

\begin{tabular}{|c|c|c|c|c|c|}
\hline \multirow[b]{2}{*}{ Patient no. } & \multirow[b]{2}{*}{ Additional diagnosis } & \multicolumn{2}{|c|}{ Coons test } & \multicolumn{2}{|c|}{$\begin{array}{l}\text { Complement- } \\
\text { fixation test }\end{array}$} \\
\hline & & Thryoidal & Adrenal & Adrenal & Kidney \\
\hline $1-17$ & IH & - & - & & \\
\hline $18^{\mathrm{b}}$ & IH & - & + & - & - \\
\hline $19^{\mathrm{b}}$ & IH & - & + & - & \\
\hline $20^{\mathrm{b}}$ & IH & - & - & - & - \\
\hline 21 & $\mathrm{IH}$ & + & - & & \\
\hline $22^{f}$ & $\mathrm{IH}$, monil. & - & - & - & - \\
\hline 23 & IH, monil. & - & - & & \\
\hline 24 & IH, monil. & - & - & - & + \\
\hline 25 & IH, monil. & - & I $[4]$ & - & \\
\hline 26 & IH, monil. & - & $+[4]$ & $\bar{z}$ & \\
\hline $27-29$ & $\begin{array}{c}\text { IH, monil., PA } \\
\text { Suroical he }\end{array}$ & $\bar{z}$ & $\pm[1]$ & - & + \\
\hline $\begin{array}{l}28-29 \\
30-32\end{array}$ & $\begin{array}{l}\text { Surgical hypoparathyroid } \\
\text { Monil. }\end{array}$ & $\overline{-}$ & $z$ & - & \\
\hline $33^{\mathrm{e}}$ & Monil. & - & - & - & \\
\hline $34-39$ & Pseudohypoparathyroid & - & - & & \\
\hline $\begin{array}{l}40-42 \\
43\end{array}$ & $\begin{array}{l}\text { Parathyroid adenoma } \\
\text { Parathyroid adenoma }\end{array}$ & $\bar{t}$ & 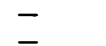 & - & \\
\hline 44 & $\begin{array}{l}\text { Parathyroid adenoma } \\
\text { Vitamin D-resistant rickets }\end{array}$ & \pm & $=$ & & \\
\hline $45-66$ & Hash. & + & - & - & \\
\hline $67-72$ & Hash. & - & - & - & \\
\hline $\begin{array}{c}73-92 \dagger \\
93-95+\end{array}$ & & $\bar{t}$ & $\overline{-}$ & $\overline{-}$ & \\
\hline $\begin{array}{l}93-95 \uparrow \\
96-101\end{array}$ & Cushing's adrenal hyperplasia & I & - & - & \\
\hline $102-103$ & Adrenal carcinoma & - & - & - & \\
\hline $104-121$ & VAH & - & - & - & \\
\hline $122-124$ & VAH & - & - & & \\
\hline
\end{tabular}

* Symbols as in Table I. Also, VAH, virilizing adrenal hyperplasia.

$\dagger$ Normal siblings and parents of Addisonian patients.

Organ specificity of adrenal antibodies. One interpretation of these studies is that the adrenal antibodies are organ specific. The Coons test was performed with a variety of tissues to investigate this possibility. The adrenal medulla did not fluoresce with any of the 36 sera giving a positive Coons test to adrenal cortex. Of these 36 sera, 5 were tested against frozen sections of liver, 9 against kidney sections, and 15 against pheochromocytoma sections. No fluorescence was observed. Fluorescence of the intercalated ducts of salivary tissue, however, was noted when 8 of the 36 sera containing adrenal antibodies were tested against parotid glands. As previously mentioned, no correlation could be made between the serum titer giving a positive Coons test against adrenal tissue and that giving a positive test against salivary tissue.

Sera 4, 29, 30, and 34 (Table I) were each titered at doubling dilutions and used in the indirect Coons test against human adrenal tissue (Table III). Simultaneously, comparable serum. dilutions were absorbed with extracts from a parathyroid adenoma and a monilial culture obtained from a patient with generalized moniliasis (see Methods). Absorption of serums with these extracts did not decrease the reactivity of the adrenal antibodies in the Coons test, although absorption with adrenal extract completely blocked the reactions.

TABLE III

Absorption of sera containing adrenal antibodies with extracts of a parathyroid adenoma and a monilia culture*

\begin{tabular}{|c|c|c|c|c|c|c|c|c|c|c|c|c|c|c|c|c|c|c|c|c|}
\hline \multirow[b]{2}{*}{ Serum dilutions: } & \multicolumn{7}{|c|}{ Serum 4} & \multicolumn{5}{|c|}{ Serum 29} & \multicolumn{4}{|c|}{ Serum 30} & \multicolumn{4}{|c|}{ Serum 34} \\
\hline & $1: 2$ & $1: 4$ & $1: 8$ & $1: 16$ & $1: 32$ & $1: 64$ & $1: 128$ & $1: 2$ & $1: 4$ & $1: 8$ & $1: 16$ & $1: 32$ & $1: 2$ & $1: 4$ & $1: 8$ & $1: 16$ & $1: 2$ & $1: 4$ & $1: 8$ & $1: 16$ \\
\hline $\begin{array}{l}\text { Serum only } \\
\text { Serum + adrenal } \\
\text { Serum + parathryoid } \\
\text { Serum + monilia, A } \\
\text { Serum + monilia, B }\end{array}$ & $\begin{array}{l}4+ \\
0 \\
3+ \\
4+ \\
4+\end{array}$ & $\begin{array}{l}3+ \\
0+ \\
3+ \\
3+ \\
4+\end{array}$ & $\begin{array}{l}2+ \\
0 \\
2+ \\
2+ \\
3+\end{array}$ & $\begin{array}{l}2+ \\
0 \\
2+ \\
2+ \\
2+\end{array}$ & $\begin{array}{l}1+ \\
0+ \\
1+ \\
1+ \\
\pm\end{array}$ & $\begin{array}{l}\mathbf{0} \\
\mathbf{0} \\
\mathbf{0} \\
\mathbf{0} \\
\pm\end{array}$ & $\begin{array}{l}\mathbf{0} \\
\mathbf{0} \\
\mathbf{0} \\
\mathbf{0} \\
\mathbf{0}\end{array}$ & $\begin{array}{l}4+ \\
0 \\
3+ \\
3+\end{array}$ & $\begin{array}{l}3+ \\
0 \\
4+ \\
2+\end{array}$ & $\begin{array}{l}1+ \\
0 \\
2+\end{array}$ & $\begin{array}{l}2+ \\
0 \\
2+ \\
1+\end{array}$ & $\begin{array}{l} \pm \\
\mathbf{0} \\
\pm \\
\mathbf{0}\end{array}$ & $\begin{array}{l}2+ \\
0 \\
4+\end{array}$ & $\begin{array}{l}2+ \\
\mathbf{0}+ \\
3+\end{array}$ & $\begin{array}{l}2+ \\
0 \\
2+\end{array}$ & $\begin{array}{l}\mathbf{0} \\
\mathbf{0} \\
\mathbf{0}\end{array}$ & $\begin{array}{l}4+ \\
0+ \\
4+\end{array}$ & $\begin{array}{l}2+ \\
0 \\
2+\end{array}$ & $\begin{array}{l}\mathbf{0} \\
\mathbf{0} \\
\mathbf{0}\end{array}$ & $\begin{array}{l}\mathbf{0} \\
\mathbf{0} \\
\mathbf{0}\end{array}$ \\
\hline
\end{tabular}

* $\mathrm{A}=50 \%$ suspension of monilial cells; $\mathrm{B}=$ monilial cells exposed to ultrasonic vibration. 
Similarly, the adrenal antibodies in serum 4 were not absorbed with microsomes from kidney, liver, thyroid, or pheochromocytoma tissue. The microsomes from adrenal tissue, however, which weighed only $1 / 8$ to $1 / 14$ as much as the tissue yielding the microsomes from kidney, liver, thyroid, and pheochromocytoma, blocked the reaction (Table IV). This experiment was repeated, with virtually the same results.

Species specificity of adrenal antibodies. The indirect Coons test also was used to evaluate the species specificity of the adrenal antibodies. Eleven sera positive for human adrenal antibodies were titered and tested against canine adrenal slices (Table V). Four of these sera were tested against the adrenal glands of other species. The titers giving a positive reaction against adrenal tissue from the human, monkey, guinea pig, cow, pig, and cat were similar. Fourteen Addisonian sera giving a negative indirect Coons test with human adrenal slices and 10 sera from normal persons failed to produce fluorescence when tested with bovine adrenal slices. Therefore, no nonspecific fluorescence was observed when animal adrenal tissue was used.

Different types of adrenal antibodies. Since a positive Coons test may reflect the presence of one or more antibodies, the CF test was used to determine if more than one $\mathrm{CF}$ antibody could be demonstrated. In the $\mathrm{CF}$ reaction, serum 23 (Table VI) reacted at a high serum dilution, but only with a high concentration of antigen. We have termed the $\mathrm{CF}$ antibody in this serum $\mathrm{CF}$ $A_{1}$. In contrast, serum 26 (Table VI) reacted at a lower serum dilution but with a weak anti-
TABLE IV

Absorption of serum 4 diluted 1:8 with microsomes from various tissues

\begin{tabular}{ccl}
\hline Tissue & $\begin{array}{c}\text { Micro- } \\
\text { somes* }\end{array}$ & $\begin{array}{c}\text { Adrenal } \\
\text { Coons } \\
\text { reaction }\end{array}$ \\
\hline Control & g tissue & \\
Adrenal & 0 & $3+$ \\
& 2.00 & 0 \\
Kidney & 1.00 & 0 \\
Liver & 0.50 & 0 \\
Thyroid & 0.20 & $2+$ \\
& 5.50 & $3+$ \\
Pheochromocytoma & 5.50 & $3+$ \\
& 7.00 & $3+$ \\
& 4.00 & $3+$
\end{tabular}

* Expressed as total grams of tissue from which microsomes were extracted to absorb $1 \mathrm{ml}$ of diluted serum.

gen concentration. This indicated a separate antigen-antibody complex $\left(\mathrm{CF} \mathrm{AB}_{2}\right)$, although the antigen in both systems may be the same. Serum 4 reacted at both high serum and weak antigen dilutions, indicating a high titer of adrenal CF $\mathrm{AB}_{2}$. The same findings were demonstrated when bovine adrenal tissue was used as the antigen.

Both immunoelectrophoresis and agar slants were used in an attempt to demonstrate the presence of one or more precipitating antigen-antibody complexes. Sera $4,6,20,23,26$, and 34 (Table I) were used in immunoelectrophoresis, and sera 4, 20, and 29 were tested with agar slants. No precipitating antibodies could be demonstrated by either technique.

Characteristics of the adrenal antigen. The antigen responsible for the positive Coons test

TABLE V

Species specificity of adrenal antigen determined by titration of sera containing antiadrenal antibodies against adrenal slices of various species used in Coons test

\begin{tabular}{|c|c|c|c|c|c|c|c|}
\hline Serum no.* & Human & Canine & Bovine & Porcine & Simian & Guinea pig & Feline \\
\hline $\begin{array}{l}4 \\
29 \\
12 \\
15 \\
30 \\
26 \ddagger \\
19 \\
10 \\
11 \\
2 \\
14\end{array}$ & $\begin{array}{l}1: 32 \dagger \\
1: 8 \\
1: 4 \\
1: 16 \\
1: 32 \\
1: 4 \\
1: 32 \\
1: 1 \\
1: 1 \\
1: 1 \\
1: 8\end{array}$ & $\begin{array}{l}1: 64 \\
1: 16 \\
1: 8 \\
1: 32 \\
1: 32 \\
1: 2 \\
1: 32 \\
1: 1 \\
1: 1 \\
1: 2 \\
1: 8\end{array}$ & $\begin{array}{l}1: 64 \\
1: 8 \\
1: 4 \\
1: 32\end{array}$ & $\begin{array}{l}1: 128 \\
1: 16 \\
1: 4 \\
1: 64\end{array}$ & $\begin{array}{l}1: 64 \\
1: 16 \\
1: 8 \\
1: 32\end{array}$ & $\begin{array}{l}1: 16 \\
1: 8 \\
1: 4 \\
1: 64\end{array}$ & $1: 64$ \\
\hline
\end{tabular}

* Listed in Table I.

+ Weakest serum titer positive to Coons test.

$\ddagger$ See Table II. 
TABLE VI

Complement-fixing titers of adrenal antibodies compared for three sera*

\begin{tabular}{|c|c|c|c|c|c|c|c|c|}
\hline \multirow{2}{*}{$\begin{array}{c}\text { Serum } \\
\text { no. }\end{array}$} & \multirow{2}{*}{$\begin{array}{l}\text { Antigen } \\
\text { dilution }\end{array}$} & \multirow[b]{2}{*}{ Undiluted } & \multicolumn{6}{|c|}{ Serum dilution } \\
\hline & & & $1: 2$ & $1: 4$ & $1: 8$ & $1: 16$ & $1: 33$ & $1: 64$ \\
\hline 23 & $\begin{array}{l}0.02 \\
0.01 \\
0.005 \\
0.0025 \\
0.0012 \\
0.0006\end{array}$ & $\begin{array}{l}4+ \\
2+ \\
0 \\
0 \\
0 \\
0\end{array}$ & $\begin{array}{l}4+ \\
2+ \\
0 \\
0 \\
0 \\
0\end{array}$ & $\begin{array}{l}4+ \\
2+ \\
0 \\
0 \\
0 \\
0\end{array}$ & $\begin{array}{l}4+ \\
2+ \\
0 \\
0 \\
0 \\
0\end{array}$ & $\begin{array}{l}4+ \\
1+ \\
0 \\
0 \\
0 \\
0\end{array}$ & $\begin{array}{l}0 \\
0 \\
0 \\
0 \\
0 \\
0\end{array}$ & $\begin{array}{l}0 \\
0 \\
0 \\
0 \\
0 \\
0\end{array}$ \\
\hline 26 & $\begin{array}{l}0.02 \\
0.01 \\
0.005 \\
0.0025 \\
0.0012 \\
0.0006\end{array}$ & $\begin{array}{l}4+ \\
4+ \\
4+ \\
4+ \\
4+\end{array}$ & $\begin{array}{l}4+ \\
4+ \\
4+ \\
4+ \\
4+ \\
\text { not }\end{array}$ & $\begin{array}{c}4+ \\
3+ \\
3+ \\
3+ \\
4+ \\
\text { done }\end{array}$ & $\begin{array}{l}1+ \\
1+ \\
0 \\
0 \\
0\end{array}$ & $\begin{array}{l}0 \\
0 \\
0 \\
0 \\
0\end{array}$ & $\begin{array}{l}0 \\
0 \\
0 \\
0 \\
0\end{array}$ & $\begin{array}{l}0 \\
0 \\
0 \\
0 \\
0\end{array}$ \\
\hline 4 & $\begin{array}{l}0.02 \\
0.01 \\
0.005 \\
0.0025 \\
0.0012 \\
0.0006\end{array}$ & $\begin{array}{l}4+ \\
4+ \\
4+ \\
4+ \\
4+ \\
2+\end{array}$ & $\begin{array}{l}4+ \\
4+ \\
4+ \\
4+ \\
4+ \\
2+\end{array}$ & $\begin{array}{l}4+ \\
4+ \\
4+ \\
4+ \\
4+ \\
2+\end{array}$ & $\begin{array}{l}4+ \\
4+ \\
4+ \\
4+ \\
4+ \\
2+\end{array}$ & $\begin{array}{l}4+ \\
4+ \\
4+ \\
4+ \\
4+ \\
1+\end{array}$ & $\begin{array}{l}3+ \\
1+ \\
2+ \\
2+ \\
3+ \\
1+\end{array}$ & $\begin{array}{l}0 \\
0 \\
0 \\
0 \\
0 \\
0\end{array}$ \\
\hline
\end{tabular}

* Interpretation of data is that there are two separate complement-fixing antibodies for adrenal tissue.

was found in both the microsomal and mitochondrial fractions. After ultracentrifugation of fresh adrenal homogenates, serial dilutions of the microsomal and mitochondrial fractions were made. The protein concentration was determined, and inhibition of the Coons test against adrenal tissue with microsomes and mitochondria was evaluated (Table VII). Both adrenal microsomes and mitochondria in appropriate dilutions could block the indirect Coons test. Serum 4 was used in all experiments.

The antigenic concentration, as related to protein concentration, was slightly greater in the

\section{TABLE VII}

Localization of adrenal antigens in both microsomes and mitochondria of adrenal tissue*

\begin{tabular}{cccccc}
\hline & \multicolumn{2}{c}{ Microsomes } & & \multicolumn{2}{c}{ Mitochondria } \\
\cline { 2 - 3 } \cline { 5 - 6 } $\begin{array}{c}\text { Adrenal } \\
\text { gland }\end{array}$ & Proteint & $\begin{array}{c}\text { Coons } \\
\text { Test }\end{array}$ & & Proteint & $\begin{array}{c}\text { Coons } \\
\text { Test }\end{array}$ \\
\cline { 5 - 6 } No. 1 & $m g$ & & & $m g$ & \\
& 0 & $3+$ & & 0 & $3+$ \\
& $1.08 *$ & 0 & & $1.25 *$ & 0 \\
& 0.54 & 0 & & 0.95 & 0 \\
No. 2 & 0.27 & 0 & & 0.63 & 0 \\
& 0.13 & $2+$ & & 0.32 & $2+$ \\
& 0 & $3+$ & & 0 & $3+$ \\
& 1.00 & 0 & & 1.23 & 0 \\
& 0.50 & 0 & 0.62 & $1+$ \\
& 0.25 & $1+$ & 0.32 & $2+$ \\
& 0.13 & $3+$ & 0.15 & $3+$ \\
& & & &
\end{tabular}

* Serum 4 (Table I) diluted 1:8 was absorbed with microsomes and mitochrondria from two separate adrenal glands.

+ Milligrams protein to absorb $1 \mathrm{ml}$ of diluted serum. microsomal than in the mitochondrial fraction. The antigenic potency of the nuclear fraction was not evaluated. Since only one serum was evaluated, and this serum may contain only one antibody, it is not known whether all adrenal antigens occur in both microsomes and mitochondria.

The effect of extreme temperature on microsomal antigen was evaluated. For this purpose, $0.54 \mathrm{mg}$ of microsomal protein per $\mathrm{ml}$ of diluted serum was used, an amount shown to be in excess of that necessary to block completely the Coons reaction to adrenal antigen (Table VII, experiment 1). Boiling the microsomes in water for 5 minutes destroyed the antigen. After repeated slow freezing and thawing for 10 times, the antigen retained its potency, and the Coons test was inhibited. Therefore, heat lability but cold stability of the antigen were demonstrated.

To determine whether hydrocortisone was an adrenal antigen involved in the positive Coons test, cortisol was added to a concentration of 500 $\mu \mathrm{g}$ per $100 \mathrm{ml}$ to serum 4 . The titer of this serum both with and without added cortisol was $1: 32$, indicating no inhibition of the antibodies with hydrocortisone.

\section{DISCUSSION}

By the indirect Coons technique, circulating adrenal antibodies have been found in sera of $51 \%$ of 71 patients with Addison's disease. In a previ- 
ous report (3) concerning 31 of these 71 , this incidence was similar $(53 \%)$. Significantly, none of 29 patients with adrenal tumors, idiopathic Cushing's syndrome, or virilizing adrenal hyperplasia had demonstrable adrenal antibodies. Equally important was the finding that the sera of only 4 of 124 subjects without Addison's disease had adrenal antibodies demonstrable by the indirect fluorescein method, and one of these four (no. 18, Table II) was known to have limited cortisol excretion secondary to adrenocortical stimulation (8). Therefore, it is probable that the demonstration of circulating adrenal antibodies by the fluorescein technique reflects the presence of an atrophic and not hyperplastic adrenal disease.

Since adrenal antibodies have been shown to be organ specific, the first criterion in establishing Addison's disease as an autoimmune process has been met, i.e., specific antibodies of the circulating type have been directly demonstrated. The isolation of specific antigens in the adrenal cortical microsomes and mitochondria meets the second criterion. The third criterion is that antibodies must be produced in animals with the same type of antigen. Witebsky and Milgrom (9) and Milcou, Pop. Lupulescou, and Taga (10) have successfully induced the formation of circulating antibodies to homologous adrenal tissue in animals. In guinea pigs, the adrenal antibodies were both organ specific and species specific. In rabbits, as not in guinea pigs, but as for the circulating antibodies of Addisonian patients, the antibodies were species specific but not organ specific (9). Witebsky and Milgrom $(1,9)$ found that the adrenal antigen inducing antibody formation in animals was thermolabile, like that in the microsomes of the human adrenal gland, and probably located in the adrenal cortex.

As for the fourth criterion to establish Addison's disease as an autoimmune process, investigators (9-12) have attempted to produce adrenal atrophy in animals by immunizing them with homologous adrenal extracts. Milgrom and Witebsky (9) reported that lymphocytic infiltration occurred throughout the adrenal cortex, although most of it occurred at the corticomedullary border zone and extended into the inner medulla. Rabbits immunized with extracts of other organs and Freund's adjuvant occasionally had similar lesions. Milccu and associates (10) noted multiple lesions in both zones of the adrenal glands of isoimmunized rabbits. In the cortex, the histopathology consisted of lymphocytic infiltration, granulocytic and fibroblastic infiltration, interstitial hemorrhage, and thrombotic obstruction of the capillaries and arterioles. The changes reported in the cortex of the animals immunized by Colover and Glynn (12) possibly were more marked than those produced by other investigators. In the parenchymal cells of the cortex, degenerative changes in the cytoplasm and nuclei were observed, and there was gross infiltration of the cortex with histiocytic elements, macrophages, lymphocytes, occasional plasma cells, and eosinophils. In some glands, the zona reticularis was particularly affected, and its parenchymal cells were largely replaced by infiltrating cells. The medullas of many glands were also severely affected. Although none of the investigators have reported adrenal atrophy occurring secondary to immunization, the histopathology of the adrenal glands of immunized animals and that recorded for adrenal atrophy in humans have some characteristics in common; i.e., Guttman (13) and Duff and Bernstein (14) reported that in the adrenal remnants of some Addisonian patients, lymphocytic infiltration occurs in the medulla and in the remaining remnants of cortical cells. Therefore, the fourth criterion has been partially met, although not so completely as the other criteria.

Although several criteria of idiopathic Addison's disease as an autoimmune process have been established, the role of the circulating antibodies has not been determined. These antibodies may only reflect the disease process and not be responsible for it, and the possible role of cellular antibodies must be considered. Experiments of Felix-Davies and Waksman (15) and of McMaster, Lerner, and Exum (16) suggest that cellular antibodies are responsible for lymphocytic infiltration of the thyroid in autoimmune thyroidal disease. Since lymphocytic thyroiditis has long been recognized as frequently associated with Addison's disease (17), further support is lent to the concept that Addison's disease may also result from an autosensitization process, possibly caused by cellular antibodies.

The high incidence of thyroidal antibodies in sera of Addisonian patients (22 of 71) suggests that in some persons multiple endocrine deficien- 
cies occur, and all of these deficiencies may be associated with autoimmune processes. As noted above, the coincident occurrence of lymphocytic thyroiditis, with or without hypothyroidism, and Addison's disease was first recognized in 1930 (17). The triad of Addison's disease, hypoparathyroidism, and moniliasis has been recorded frequently $(8,18)$. Twelve of our 71 Addisonian patients had associated hypoparathyroidism, and 7 of the 12 also had moniliasis. The sera of 10 of these 12 were positive when tested for adrenal antibodies. Since the adrenal antibodies are organ specific, multiple circulating antibody-antigen complexes probably are involved in the autoimmune processes. The possibility, however, of a common cellular antibody-antigen system between multiple endocrine glands must be considered; further studies are necessary to elucidate it.

\section{SUMMARY}

Circulating adrenal antibodies, tested by the indirect Coons test, were found in 36 of 71 sera from Addisonian patients. Complement-fixing antibodies were found in 24 of these 36 sera. The circulating antibodies were organ specific but not species specific. There was no cross-reactivity with tissue of the adrenal medulla, pheochromocytoma, thyroid, salivary gland, liver, or kidney, and none with monilial organisms. The antigen(s) to which the circulating antibodies are produced is in both the microsomal and mitochondrial fractions. Some of the physical characteristics of the antigen(s) have been studied. Further work is indicated to clarify the significance of circulating adrenal antibodies in Addison's disease.

\section{ACKNOWLEDGMENTS}

We gratefully acknowledge the cooperation of the many physicians who assisted in the collection of sera, the review and criticisms of the manuscript by Dr. Irene Solomon, and the secretarial assistance of Mrs. Mary Westervelt.

\section{REFERENCES}

1. Witebsky, E. The question of self-recognition by the host and problems of auto-antibodies and their specificity. Cancer Res. 1961, 21, 216.

2. Witebsky, E., N. R. Rose, K. Terplan, J. R. Paine, and R. W. Egan. Chronic thyroiditis and auto- immunization. J. Amer. med. Ass. 1957, 164, 1439.

3. Blizzard, R. M., M. A. Kyle, R. W. Chandler, and W. Hung. Adrenal antibodies in Addison's disease. Lancet 1962, 2, 901.

4. Holborow, E. J., P. C. Brown, I. M. Roitt, and D. Doniach. Cytoplasmic localization of "complement-fixing" auto-antigen in human thyroid epithelium. Brit. J. exp. Path. 1959, 40, 583.

5. Chandler, R. W., R. M. Blizzard, W. Hung, and M. Kyle. Incidence of thyrocytotoxic factor and other antithyroid antibodies in the mothers of cretins. New Engl. J. Med. 1962, 267, 376.

6. Blizzard, R. M., R. W. Chandler, B. H. Landing, M. D. Pettit, and C. D. West. Maternal autoimmunization to thyroid as a probable cause of athyrotic cretinism. New Engl. J. Med. 1960, 263, 327.

7. Kabat, E. A., and M. M. Mayer. Experimental Immunochemistry. Springfield, Ill., Charles C Thomas, 1961, p. 476.

8. Morse, W. I., W. A. Cochrane, and P. L. Landrigan. Familial hypoparathyroidism with pernicious anemia, steatorrhea, and adrenocortical insufficiency. New Engl. J. Med. 1961, 264, 1021.

9. Witebsky, E., and F. Milgrom. Immunological studies on adrenal glands. II. Immunization with adrenals of the same species. Immunology 1962, 5,67 .

10. Milcou, S. M., A. Pop, A. Lupulescou, and M. Taga. L'auto-immunisation expérimentale de la surrénale chez le lapin. Ann. d'Endocr. (Paris) 1959, 20, 799.

11. Steiner, J. W., B. Langer, D. L. Schatz, and R. Volpe. Experimental immunologic adrenal injury. A response to injections of autologous and homologous adrenal antigens in adjuvant. J. exp. Med. 1960, 112, 187

12. Colover, J., and L. E. Glynn. Experimental iso-immune adrenalitis. Immunology 1958, 1, 172.

13. Guttman, P. H. Addison's disease. A statistical analysis of five hundred and sixty-six cases and a study of the pathology. Arch. Path. 1930, 10, 742.

14. Duff, G. L., and C. Bernstein. Five cases of Addison's disease with so-called atrophy of adrenal cortex. Bull. Johns Hopk. Hosp. 1933, 52, 67.

15. Felix-Davies, D., and B. H. Waksman. Passive transfer of experimental immune thyroiditis in the guinea pig. Arthr. and Rheum. 1961, 4, 416.

16. McMaster, P. R. B., E. M. Lerner II, and E. D. Exum. The relationship of delayed hypersensitivity and circulating antibody to experimental allergic thyroiditis in inbred guinea pigs. J. exp. Med. 1961, 113, 611.

17. Wells, H. G. Addison's disease with selective destruction of the suprarenal cortex ("suprarenal cortex atrophy"). Arch. Path. 1930, 10, 499.

18. Craig, J. M., L. H. Schiff, and J. E. Boone. Chronic moniliasis associated with Addison's disease. Amer. J. Dis. Child. 1955, 89, 669. 